\begin{tabular}{|c|c|}
\hline 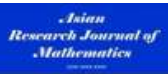 & Asian Research Journal of Mathematics \\
\hline & $\begin{array}{l}\text { 5(2): 1-12, 2017; Article no.ARJOM.34046 } \\
\text { ISSN: } 2456-477 X\end{array}$ \\
\hline $\mathbb{9}$ & \\
\hline
\end{tabular}

\title{
A Markov Chain Model Approach to Study Academic Promotions in Ghanaian Universities
}

\author{
Buckman Akuffo $^{1 *}$, Samuel Okae - Adjei ${ }^{2}$ and Paul Baah ${ }^{3}$ \\ ${ }^{I}$ Department of Applied Mathematics, Faculty of Applied Science and Technology, Koforidua Technical \\ University, Koforidua, Ghana. \\ ${ }^{2}$ Department of Marketing, Faculty of Business and Management Studies, Koforidua Technical University, \\ Koforidua, Ghana. \\ ${ }^{3}$ Department of Liberal Studies, Faculty of Business and Management Studies, Koforidua Technical \\ University, Koforidua, P.O. Box KF 981, Ghana.
}

\begin{abstract}
Authors' contributions
This work was carried out in collaboration between all authors. Authors BA and SOA designed the study, performed the statistical analysis, wrote the protocol and wrote the first draft of the manuscript. Authors BA and PB managed the analyses of the study. Authors SOA and PB managed the literature searches. All authors read and approved the final manuscript.
\end{abstract}

Article Information

DOI: $10.9734 /$ ARJOM/2017/34046

Editor(s):

(1) Gongxian Xu, Associate Professor, Department of Mathematics, Bohai University, Jinzhou, China.

Reviewers:

(1) Huilin Huang, Wenzhou University, China.

(2) Syed Muhammed Aqil Burney, Institute of Business Management Karachi, Pakistan. (3) Emilija Kisić, School of Electrical Engineering and Computer Science of Applied Studies, Serbia.

(4) S. K. Srivatsa, Anna University, India. (5) Diana Bílková, University of Economics, Czech Republic. (6) Ajay Auddy, The University of Burdwan, India. Complete Peer review History: http://www.sciencedomain.org/review-history/20017

Original Research Article

Received: $11^{\text {th }}$ May 2017

Accepted: $26^{\text {th }}$ June 2017

Published: 12 ${ }^{\text {th }}$ July 2017

\begin{abstract}
Promotions of academic staff in universities and analogous institutions remain crucial to the attainment of economic, environmental and societal objectives nationally and globally. Notwithstanding the benefits to institutions and individuals, little literature is available on outlay of promotions in universities in Ghana. This paper seeks to model promotions in Ghanaians universities as stochastic process to determine the underlining stochasticness under different conditions. Stochastic model with emphasis on the an absorbing Markov Chain, presented in its canonical form, was used to estimate the probability of lecturers attaining professorial status before retiring from service, and also the average length of time an academic
\end{abstract}

*Corresponding author: E-mail: kofisakyiba@gmail.com; 
staff stays in the universities. A simple random sample was used to select three Ghanaian universities (a public university, a private university and then a technical university) and data on promotions of academic was collected from these universities. The study found out that, whereas an academic staff spends an average of 21 years in a technical university, colleagues in the public university spends a lower average of about 13 years. Again, the study revealed that academic staffs in the public university have higher probability (26\%) of attaining professorial status as compared to their colleagues in technical universities $(25 \%)$. The estimated model indicated that a newly recruited academic staff have insignificant chance of promoted to a professorial rank in the private universities in Ghana.

Keywords: Absorbing chain; academic promotion; fundamental matrix; markov chain; stochastic process.

\section{Introduction}

Universities around the world largely exist to perform three main core functions; advancement of knowledge through research, impacting of (acquired) knowledge through teaching (in its various forms) and community service. These functions culminate into national development and competitive for a country and the world at large and need to be rewarded by participants. The achievement of universities objectives, to a large extent, depends on the academic staff because of the critical role they play in the teaching and learning process [1]. Again, [2] assert that the most attractive reward perceived by the staff is promotion and that promotion will improve the staff objective, performance and aspirations which put academics under pressure. There are many reasons for academics under pressure, but striving for academic promotion is regarded as one of the most influential factors [3-5]. Academic promotion is understood as a movement from one academic rank to another higher rank.

Academic promotions in educational institutions remain a crucial part of the development of both institutions and individuals for many reasons. It seeks to recognize and reward excellent staff. All academic staff, other than those on casual appointments, are eligible and encouraged to apply for academic promotion in universities around the world. In many instances, there are no quotas and all staff meeting the promotion standards can advance their promotion process. Contributions to teaching, research and service are all highly valued.

Academic promotions criteria are basically factored on teaching, research and publications and community service, publication being a major factor. Fundamentally, global university rankings are used to compare educational performance and productivity nationally and internationally, and measure educational quality and excellence [6]. Also, global university rankings are often used as an indication of a nation's global competitiveness, given the importance of higher education to social and economic growth and innovation [7] and [8].

As concluded by [9], promotion brings with it not only financial rewards but also a mark of recognition of the individual performance and acceptance by staff and students. Again, [9], supported the view held by [10] indicated that promotion has both positive and significant effect on job satisfaction.

The process of decision-making for academic staff promotion often involves criteria, such as tasks, activities, teaching, supervision, publications, research, consulting, conferencing, administration, and community service [11].

From [12] academic staff appraisal can also be evaluated through items, such as research articles produced, teaching method, presentation style, and involvement in university and community activities which at the end culminate to promotion of the individual.

The Ghanaian higher education system has been under transformation since 1960s with the changing system of government. Academic profession in Ghana has also been changing under the impact of various 
approaches of new public management by the Ministry of Education. One important aspect of all changes in the higher education system has been with the performance-based academic promotion policy. Academic ranks in Ghanaian universities typically include 'lecturer', 'senior lecturer', 'associate professor', and 'full professor'.

Different categories of staff have different promotional criteria and are encouraged to seek for promotions as and when individuals are prepared. The different criteria, normally established by the various governing councils of universities (public and private), have some level of discrepancies and few similarities. That is inasmuch as promotions are important to organizations and individuals, various factors come into play before it is initiated or effected.

Notwithstanding, the importance of promotions, to institutions and individuals, factors and events leading to academic promotions are left to chance and at the express determination of individuals. This means that, unlike deterministic models, promotions in higher institutions in Ghana are random events and can be modeled as such.

How often are academic staff promoted and hence performance; among the public universities, private universities and the technical universities, which group has higher chance of a staff being promoted and to what grade? Is it more probable to be promoted to professorial status in a private university than a in public university? Finally, what are the attritions rates at the various grades in the universities in Ghana? Answers to these questions would help academic staff and university administrators and Policy formulators would be guided to formulate the right policies and finance appropriate developmental projects and help staff wanting to choose which university to stay and progress.

Modelling and formulating processes such as academic promotion has taken many dimensions but little is said of statistical application to this vital part of educational institutions. Considering the fact that promotion process is a form of transition that academic staffs go through, and at the end of their tenure, they shall retire on the grade of professor or non-professor, the process of academic promotions can assume a stochastic absorbing process. A successful application of academic process as stochastic process can help answer the following questions:

(i) What is the average length of time a lecturer spends working in a particular university?

(ii) For how long do the universities make use of lecturers promoted to the grade of senior lectureship?

(iii) What proportions of lecturers will retire from the universities on the various grades?

\section{Materials and Methods}

\subsection{Data}

Universities in Ghana were grouped into three; Public Universities (PU), Private Universities (PrU) and Public Technical Universities (PTUs) which were polytechnics but have recently been converted to technical universities. This, in the researchers view, was necessary because these three groups of universities have distinct environment for promotions in terms of condition of service, mode of remuneration and promotion appetite for staff.

A university each was then randomly selected from the PU, PrU and PTUs in Ghana and coded A, B and C respectively from the Public Universities (PU), Private Universities (PrU) and Public Technical Universities (PTUs). Data on promotions from Lecturer (L) to Senior Lecturer (SL), to Associate Professor (AssoProf) and then to Professor (Prof.) of academic staff for the 2015/2016 academic year was then sought from the PU, PrU and PTU.

Table 1 gives the distribution of the proportions of academic staffs who were promoted during the 2015/2016 academic year from the three sampled universities. 
Table 1. Transition of staff

\begin{tabular}{|c|c|c|c|c|c|c|c|}
\hline \multirow{2}{*}{ 苞 } & \multirow{2}{*}{$\begin{array}{l}\text { Total } \\
\text { number } \\
\text { of staff }\end{array}$} & \multicolumn{6}{|c|}{$\begin{array}{c}\text { University A } \\
\text { (A Public University) }\end{array}$} \\
\hline & & Lecturer & $\begin{array}{l}\text { Snr } \\
\text { lecturer }\end{array}$ & $\begin{array}{l}\text { Asso } \\
\text { prof }\end{array}$ & Prof. & $\begin{array}{l}\text { Leaving as } \\
\text { non prof }\end{array}$ & $\begin{array}{l}\text { Leaving } \\
\text { as prof. }\end{array}$ \\
\hline Lecturer & 265 & 234 & 22 & 0 & 0 & 9 & 0 \\
\hline Snr Lecturer & 85 & 0 & 63 & 15 & 0 & 7 & 0 \\
\hline AssoProf & 16 & 0 & 0 & 8 & 3 & 5 & 0 \\
\hline Prof. & 13 & 0 & 0 & 0 & 9 & 0 & 4 \\
\hline Leaving as non Prof. & 21 & 0 & 0 & 0 & 0 & 21 & 0 \\
\hline Leaving as a Prof. & 4 & 0 & 0 & 0 & 0 & 0 & 4 \\
\hline \multirow[t]{2}{*}{ 总 } & $\begin{array}{l}\text { Total } \\
\text { number } \\
\text { of staff }\end{array}$ & \multicolumn{6}{|c|}{$\begin{array}{c}\text { University B } \\
\text { (A Private University) }\end{array}$} \\
\hline & & Lecturer & $\begin{array}{l}\text { Snr } \\
\text { lecturer }\end{array}$ & $\begin{array}{l}\text { Asso } \\
\text { prof }\end{array}$ & Prof. & $\begin{array}{l}\text { Leaving as } \\
\text { Non prof }\end{array}$ & $\begin{array}{l}\text { Leaving } \\
\text { as prof. }\end{array}$ \\
\hline Lecturer & 85 & 68 & 2 & 0 & 0 & 15 & 0 \\
\hline Snr Lecturer & 16 & 0 & 4 & 1 & 0 & 11 & 0 \\
\hline AssoProf & 2 & 0 & 0 & 1 & 1 & 1 & 0 \\
\hline Prof. & 2 & 0 & 0 & 0 & 1 & 0 & 1 \\
\hline Leaving as non Prof. & 19 & 0 & 0 & 0 & 0 & 19 & 0 \\
\hline Leaving as a Prof. & 1 & 0 & 0 & 0 & 0 & 0 & 1 \\
\hline \multirow[t]{2}{*}{ 节 } & $\begin{array}{l}\text { Total } \\
\text { number } \\
\text { of staff }\end{array}$ & \multicolumn{6}{|c|}{$\begin{array}{c}\text { University C } \\
\text { (A Public Technical University) }\end{array}$} \\
\hline & & Lecturer & $\begin{array}{l}\text { Snr } \\
\text { lecturer }\end{array}$ & $\begin{array}{l}\text { Asso } \\
\text { Prof }\end{array}$ & Prof. & $\begin{array}{l}\text { Leaving as } \\
\text { non prof }\end{array}$ & $\begin{array}{l}\text { Leaving } \\
\text { as prof. }\end{array}$ \\
\hline Lecturer & 197 & 186 & 5 & 0 & 0 & 6 & 0 \\
\hline Snr Lecturer & 25 & 0 & 19 & 3 & 0 & 3 & 0 \\
\hline AssoProf & 3 & 0 & 0 & 1 & 1 & 1 & 0 \\
\hline Prof. & 2 & 0 & 0 & 0 & 1 & 0 & 1 \\
\hline Leaving as non Prof. & 10 & 0 & 0 & 0 & 0 & 10 & 0 \\
\hline Leaving as a Prof. & 1 & 0 & 0 & 0 & 0 & 0 & 1 \\
\hline
\end{tabular}

\subsection{Methods}

The Markov chain fundamental matrix was developed for each strata of university group. The Markov Chain fundamental matrix was formulated with the aid of the MatLab statistical programme.

\subsubsection{Markov chains}

A markov chain is a mathematics model of a random phenomenon evolving with time (discrete or continuous) in a way that the past affects the future only through the present [13]. (Konstantopoulos, 2009). Consider a (finite or infinite) sequence of random variables $\left\{X_{n}, n \in T\right\}$, where $\mathrm{T}$ is a subset of a set on integers. We conclude that this sequence has the Markov property if for any $n \in T$, the future process $\left(X_{m}, m>n, m \in T\right)$ is independent of the past process given by:

$$
\left(X_{m}, m<n, m \in T\right)
$$

which is conditionally on $X_{n}$. 
Sometimes we say the $\left(X_{n}, n \in T\right)$ is Markov instead of saying that it has the Markov property. Usually, $T=\mathrm{Z}_{+}=\{0,1,2,3, \ldots\}$ or $N=\{0,1,2,3, \ldots\}$ and the subset of $\mathrm{Z}$ of all integers (positive, zero, or negative). We focus almost exclusively to the first choice. We normally assume that $X_{n}$ take values in some countable set $\mathrm{S}$, which we refer to the state space. The elements therein $\mathrm{S}$ are called states.

In perspective, all academic staff are situated in the state space and each one has a state being, an instructor, lecturer or even a professor.

\section{$\underline{\text { 2.2.2 Absorbing markov chains }}$}

Any state, $S_{i}$ of a Markov chain is called absorbing state if once the Markov chain enter the state, it is impossible to leave that state. In general, a Markov chain is absorbing if it has at least one absorbing state and from every state it is possible to go to an absorbing state.

Thence the probability of leaving that state is zero and it is shown that the probability of the absorbing state, $p_{i i}=1$.

In an absorbing Markov chain, a state which is not absorbing is called transient. All lecturers have absorbing state of leaving the university at their current state or leaving with the ultimate promotion, as professor. This serves as the basis of modelling the promotions as a Markov stochastic process.

The transition matrix of an absorbing Markov Chain follows a Canonical form, which means that the transient states come first:

$$
P=\left(\frac{Q \mid R}{O \mid I}\right)
$$

Given that there are $\boldsymbol{t}$ transient states and $r$ absorbing states, then we define the dimensions of the four matrices in equation [1] as:

$$
O=\left(\begin{array}{ccccc}
0 & \cdot & \cdot & \cdot & 0 \\
\cdot & \cdot & \cdot & \cdot & \cdot \\
\cdot & \cdot & \cdot & \cdot & \cdot \\
\cdot & \cdot & \cdot & \cdot & \cdot \\
0 & \cdot & \cdot & \cdot & 0
\end{array}\right)
$$

as an $r \times t$ null matrix;

$$
I=\left(\begin{array}{ccccc}
1 & . & . & . & 0 \\
\cdot & 1 & \cdot & \cdot & . \\
\cdot & . & \cdot & \cdot & \cdot \\
\cdot & \cdot & \cdot & \cdot & . \\
0 & . & . & . & 1
\end{array}\right)
$$

as an $r \times r$ identity matrix; 


$$
R=\left(\begin{array}{llll}
a & \cdot & \cdot & \cdot \\
b & \cdot & \cdot & \cdot \\
c & \cdot & \cdot & \cdot \\
d & \cdot & \cdot & \cdot \\
e & f & g & h
\end{array}\right)
$$

as a non-zero $t \times r$ matrix, giving transition probabilities from transient to absorbing states; and finally

$$
Q=\left(\begin{array}{ccccc}
a & \cdot & \cdot & \cdot & g \\
\cdot & \cdot & \cdot & \cdot & \cdot \\
\cdot & \cdot & \cdot & \cdot & \cdot \\
\cdot & \cdot & \cdot & \cdot & \cdot \\
n & \cdot & \cdot & \cdot & m
\end{array}\right)
$$

As a $t \times t$ matrix, giving transition probabilities from transient to transient states.

\subsubsection{The markov chain fundamental matrix}

Haven established equations [1] to [1d] we can deduce the fundamental matrix for an absorbing Markov chain as:

$$
(I-Q)^{-1}
$$

The entries in equation [2] give the expected number of times that the process is in the transient state, say $S_{j}$ if it started in the transient state $S_{i}$.

In this paper we seek to find all possible number of times an academic staff may proceed from one status to another until such a time he or she finally leaves the institution by computing the entries for equation [2].

\subsubsection{Absorbing probabilities}

The absorbing probabilities are the entries in $t \times r$ matrix in:

$$
(I-Q)^{-1} R
$$

An entry, say, $b_{i j}$ in equation [3] is the probability that an absorbing chain will be absorbed in the state $s_{j}$ if it starts in the transient state $S_{i}$. We situate the probability of academic staff transiting or promoted to another status once equation [3] has been firmly deduced from data on promotion of academic staff.

\section{Results and Discussion}

From Table 1, we compute the probabilities of transition and presented in Table 2. 
Table 2. Transition probabilities

\begin{tabular}{|c|c|c|c|c|c|c|c|}
\hline \multirow{2}{*}{ 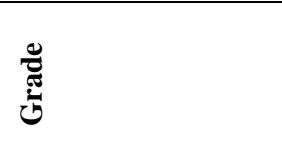 } & \multirow{2}{*}{$\begin{array}{l}\text { Total } \\
\text { number } \\
\text { of staff }\end{array}$} & \multicolumn{6}{|c|}{$\begin{array}{c}\text { University A } \\
\text { (A Public University) }\end{array}$} \\
\hline & & Lecturer & $\begin{array}{l}\text { Snr } \\
\text { lecturer }\end{array}$ & AssoProf & Prof. & $\begin{array}{l}\text { Leaving as } \\
\text { non prof }\end{array}$ & $\begin{array}{l}\text { Leaving } \\
\text { as prof. }\end{array}$ \\
\hline Lecturer & 265 & 0.88 & 0.08 & 0.00 & 0.00 & 0.03 & 0.00 \\
\hline Snr Lecturer & 85 & 0.00 & 0.74 & 0.18 & 0.00 & 0.08 & 0.00 \\
\hline AssoProf & 16 & 0.00 & 0.00 & 0.50 & 0.19 & 0.31 & 0.00 \\
\hline Prof. & 13 & 0.00 & 0.00 & 0.00 & 0.69 & 0.00 & 0.31 \\
\hline Leaving as non Prof. & 21 & 0.00 & 0.00 & 0.00 & 0.00 & 1.00 & 0.00 \\
\hline Leaving as a Prof. & 4 & 0.00 & 0.00 & 0.00 & 0.00 & 0.00 & 1.00 \\
\hline \multirow[t]{2}{*}{ 茪 } & $\begin{array}{l}\text { Total } \\
\text { number } \\
\text { of staff }\end{array}$ & \multicolumn{6}{|c|}{$\begin{array}{c}\text { University B } \\
\text { (A Private University) }\end{array}$} \\
\hline & & Lecturer & $\begin{array}{l}\text { Snr } \\
\text { lecturer }\end{array}$ & AssoProf & Prof. & $\begin{array}{l}\text { Leaving as } \\
\text { non prof }\end{array}$ & $\begin{array}{l}\text { Leaving } \\
\text { as prof. }\end{array}$ \\
\hline Lecturer & 85 & 0.80 & 0.02 & 0.00 & 0.00 & 0.18 & 0.00 \\
\hline Snr Lecturer & 16 & 0.00 & 0.25 & 0.06 & 0.00 & 0.69 & 0.00 \\
\hline AssoProf & 2 & 0.00 & 0.00 & 0.33 & 0.33 & 0.33 & 0.00 \\
\hline Prof. & 2 & 0.00 & 0.00 & 0.00 & 0.50 & 0.00 & 0.50 \\
\hline Leaving as non Prof. & & 0.00 & 0.00 & 0.00 & 0.00 & 1.00 & 0.00 \\
\hline Leaving as a Prof. & $\begin{array}{l}19 \\
1\end{array}$ & 0.00 & 0.00 & 0.00 & 0.00 & 0.00 & 1.00 \\
\hline \multirow[t]{2}{*}{ 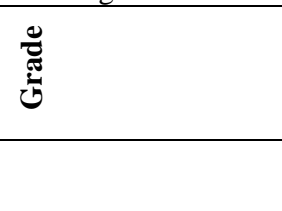 } & $\begin{array}{c}\text { Total } \\
\text { number } \\
\text { of staff }\end{array}$ & \multicolumn{6}{|c|}{$\begin{array}{c}\text { University C } \\
\text { (A Public Technical University) }\end{array}$} \\
\hline & & Lecturer & $\begin{array}{l}\text { Snr } \\
\text { lecturer }\end{array}$ & AssoProf & Prof. & $\begin{array}{l}\text { Leaving as } \\
\text { non Prof }\end{array}$ & $\begin{array}{l}\text { Leaving } \\
\text { as prof. }\end{array}$ \\
\hline Lecturer & 197 & 0.94 & 0.03 & 0.00 & 0.00 & 0.03 & 0.00 \\
\hline Snr Lecturer & 25 & 0.00 & 0.76 & 0.12 & 0.00 & 0.12 & 0.00 \\
\hline AssoProf & 3 & 0.00 & 0.00 & 0.33 & 0.33 & 0.33 & 0.00 \\
\hline Prof. & 2 & 0.00 & 0.00 & 0.00 & 0.50 & 0.00 & 0.50 \\
\hline Leaving as non Prof. & 10 & 0.00 & 0.00 & 0.00 & 0.00 & 1.00 & 0.00 \\
\hline Leaving as a Prof. & 1 & 0.00 & 0.00 & 0.00 & 0.00 & 0.00 & 1.00 \\
\hline
\end{tabular}

Hence the transition matrix for Public University as $\boldsymbol{P}_{\boldsymbol{A}}$, Private University as $\boldsymbol{P}_{\boldsymbol{B}}$, and then Technical University as $\boldsymbol{P}_{\boldsymbol{C}}$ as given as:

$$
P_{A}=\left(\begin{array}{cccccc}
0.88 & 0.08 & 0 & 0 & 0.03 & 0 \\
0 & 0.74 & 0.18 & 0 & 0.08 & 0 \\
0 & 0 & 0.50 & 0.19 & 0.31 & 0 \\
0 & 0 & 0 & 0.69 & 0 & 0.31 \\
0 & 0 & 0 & 0 & 1 & 0 \\
0 & 0 & 0 & 0 & 0 & 1
\end{array}\right)
$$


From [4] we have

$$
Q_{A}=\left(\begin{array}{cccc}
0.88 & 0.08 & 0 & 0 \\
0 & 0.74 & 0.18 & 0 \\
0 & 0 & 0.50 & 0.19 \\
0 & 0 & 0 & 0.69
\end{array}\right) ; \quad \text { and } \quad R_{A}=\left(\begin{array}{cc}
0.03 & 0 \\
0.08 & 0 \\
0.31 & 0 \\
0 & 0.31
\end{array}\right)
$$

Thence

$$
\begin{aligned}
& I_{A}-Q_{A}=\left(\begin{array}{cccc}
1 & 0 & 0 & 0 \\
0 & 1 & 0 & 0 \\
0 & 0 & 1 & 0 \\
0 & 0 & 0 & 1
\end{array}\right)-\left(\begin{array}{cccc}
0.88 & 0.08 & 0.00 & 0.00 \\
0.00 & 0.74 & 0.18 & 0.00 \\
0.00 & 0.00 & 0.50 & 0.19 \\
0.00 & 0.00 & 0.00 & 0.69
\end{array}\right)=\left(\begin{array}{cccc}
0.12 & -0.08 & 0.00 & 0.00 \\
0.00 & 0.26 & -0.18 & 0.00 \\
0.00 & 0.00 & 0.50 & -0.19 \\
0.00 & 0.00 & 0.00 & 0.31
\end{array}\right) \\
& A=\left(I_{A}-Q_{A}\right)^{-1}=\left(\begin{array}{llll}
8.55 & 2.74 & 0.97 & 0.59 \\
0.00 & 3.86 & 1.36 & 0.83 \\
0.00 & 0.00 & 2.00 & 1.22 \\
0.00 & 0.00 & 0.00 & 3.25
\end{array}\right)
\end{aligned}
$$

and

$$
A A=\left(I_{A}-Q_{A}\right)^{-1} R_{A}=\left(\begin{array}{cc}
0.82 & 0.18 \\
0.74 & 0.26 \\
0.63 & 0.38 \\
0.00 & 1.00
\end{array}\right)
$$

Similarly,

$$
B=\left(I_{B}-Q_{B}\right)^{-1}=\left(\begin{array}{llll}
5.00 & 0.16 & 0.01 & 0.01 \\
0.00 & 1.33 & 0.13 & 0.08 \\
0.00 & 0.00 & 1.50 & 1.00 \\
0.00 & 0.00 & 0.00 & 2.00
\end{array}\right)
$$

Then

$$
B B=\left(I_{B}-Q_{B}\right)^{-1} R_{B}=\left(\begin{array}{cc}
1.00 & 0.00 \\
0.96 & 0.04 \\
0.50 & 0.50 \\
0.00 & 1.00
\end{array}\right)
$$


Again,

$$
C=\left(I_{C}-Q_{C}\right)^{-1}=\left(\begin{array}{cccc}
17.91 & 1.89 & 0.34 & 0.23 \\
0.00 & 4.17 & 0.75 & 0.50 \\
0.00 & 0.00 & 1.50 & 1.00 \\
0.00 & 0.00 & 0.00 & 2.00
\end{array}\right)
$$

and

$$
C C=\left(I_{C}-Q_{C}\right)^{-1} R_{C}=\left(\begin{array}{cc}
0.89 & 0.11 \\
0.75 & 0.25 \\
0.50 & 0.50 \\
0.00 & 1.00
\end{array}\right)
$$

\subsection{What is the average length of time a lecturer spends working in a particular university?}

The sums of rows equation [2] give the average length of the respective transition states. From [4a]

$$
a_{11}+a_{12}+a_{13}+a_{14}=8.55+2.74+0.97+0.59=12.85
$$

Similarly, $b_{11}+b_{12}+b_{13}+b_{14}=5.20$ and $c_{11}+c_{12}+c_{13}+c_{14}=20.37$.

That is to say as relatively, academic staff in the technical universities spend longer period in service (20.37 years) as compared to staff in the public universities with an average service time of 12.85 years on the average. Staff in the private universities spends comparatively less time in their institutions with an average of 5.20 years according to the data.

This implies attrition rates in the private universities in Ghana are relatively higher than in the public universities. Comparing the three groups it can be said that academic staff in technical universities spends longer time in their school, hence relatively less attrition rate as compared to the attrition rate in public universities and the private universities.

Reasons for such length of stay can be attributed to the specialties technical university lecturers possess that make them very curved for their institutions according to [12] Relatively poor condition of service in the private universities can be attributed to the shorter length of average stay of their academic staff according to [14].

\subsection{For how long do the universities make use of lecturers promoted to the grade of senior lectureship?}

The first promotional transition in most universities in Ghana is from lecturer to senior lecturer. The researchers were interested in finding out the average length of time this first time promoted staff work in the institution. From equation [4a] we have

$$
a_{22}+a_{23}+a_{24}=3.86+1.36+0.0 .83=6.06
$$


Similarly,

$$
b_{22}+b_{23}+b_{24}=1.50
$$

And

$$
c_{22}+c_{23}+c_{24}=5.42
$$

That is to say, once promoted to senior lecturer, academic staff from the public universities spends an average of about 6 years whereas those from the technical universities spend 5.42 years and the least being 1.50 years the private universities before leaving the university.

Once a staff has undergone transition, the object here is to compare with the average number of years spent in the system.

Comparing with the average time spent in the university (from lecturer till leaving) as 12.85 vrs $6.06,5.20$ vrs 1.5 and 20.37 vrs 5.42, we can conclude that staff in Ghanaian universities spend appreciable time at their entering level before getting their first promotions. If academic staffs are promoted relatively earlier, the university stands the chance of using them for an appreciable time before leaving and this will, in no means boost productivity.

\subsection{What proportions of lecturers will retire from the universities on the various grades?}

Equation [3] gives the probabilities of various transitions. We appeal to equations [4b], [5b] and [6b] to find the proportions.

$$
A A=\left(\begin{array}{ll}
0.82 & 0.18 \\
0.74 & 0.26 \\
0.63 & 0.38 \\
0.00 & 1.00
\end{array}\right), \quad B B=\left(\begin{array}{ll}
1.00 & 0.00 \\
0.96 & 0.04 \\
0.50 & 0.50 \\
0.00 & 1.00
\end{array}\right), \quad C C=\left(\begin{array}{cc}
0.89 & 0.11 \\
0.75 & 0.25 \\
0.50 & 0.50 \\
0.00 & 1.00
\end{array}\right)
$$

Appealing to equation [4b], the percentage of academic staff that started as lecturers and shall retire as nonprofessors, is given as $a a_{12}=0.82$ starting. That is to say about $82 \%$ of academic staff who were recruited as lecturers would retire as non-professors whereas $89 \%$ of lecturers would retire as non-professors from the technical universities according to equation [6b]. However, based on the current process the chance of an academic staff recruited as lecturer to retire on a professorial status is zero.

Whereas it is estimated that $26 \%$ of current senior lecturers would leave the tradition universities as professors, $25 \%$ can be predicted for their counterparts in the technical universities and only $4 \%$ can be said of same status from the private universities.

It is instructive to note that $50 \%$ of associate professors from both the private and technical universities are estimated to retire as full professors but this estimated probability is $38 \%$ in the public universities. Of course all current professors would retire on their status as professors hence $a a_{42}=b b_{42}=c c_{42}=1$.

\section{Conclusion}

Academic promotion shall continue to play a significant role in the performance measurement of higher institutions [15] and institutions in Ghana cannot be exception. Hence, the need for robust model for 
informed decision- making by institutional managers for planning as well as academic staff on further plans and aspiration is increasingly becoming imperative. The study has shown that transition records of promotions can be modelled as a stochastic process and the time estimates and proportion of staff at various transition levels estimated. The results show that, based on recent data, staff in technical universities, on the average stays longer in their institutions (20.37 years) than their counter parts from the public universities (12.85 years) in Ghana. Again, the results show that it is more likely for new recruited lecturers in a public university to attain professorial status than their counterparts in the technical university whereas those in private universities have very low(in fact probability of zero) of being promoted to a professorial status. The findings from is paper is motivating the authors to expand the sample for the study. Again, further works can be conducted on other absorbing scenario using the conclusion on this basis for the length of time and probabilities of academic staff in the institutions.

\section{Competing Interests}

Authors have declared that no competing interests exist.

\section{References}

[1] Demitrii O, Logofet, Lesnaya EV. The mathematics of Markov models: What Markov can really predict in forest successions. Ecological Modeling. 2000;126(2 - 3):285-298.

[2] Mustaffa, Kamis. Academic reward systems among Ghanaian universities: Implantation process and challenges. International Journal of Educational Science. 2007;14(3):25-34.

[3] Li LL. A research summary of domestic college teachers' professional status. Journal of Anhui Electronic Engineering Professional Technique College. 2010;15(2):118-122.

[4] Liu ZC, Sun J. Commenting on scientific research pressure of universities teachers and alleviating measures. Journal of Hunan Agricultural University (Social Science). 2009;10(4):67-70.

[5] Wang YN, Zhu XY. A survey from Nanhang university shows: Academic profession is the biggest reason for academic pressure; 2011.

Available:http://learning.sohu.com/20110525/n308447390.shtml/

(Retrieved 05/05, 2017)

[6] Hazelkorn E. How rankings are reshaping higher education? Paper presented at the IAU 13th General Conference, Utrecht, The Netherlands; 2013.

[7] Marginson S, Van der Wende M. To rank or to be ranked: The impact of global rankings in higher education. Journal of Studies in International Education. 2007;11(3-4):306-329.

[8] Van der Wende. Sustaining academic progress through objective evaluation of research in Nigeria. College Teaching Methods \& Styles Journal. 2007;4(8):27-31.

[9] Ubeku AK. Personnel management in Nigeria. Benin City: Ethiopia Publishing Company; 1975.

[10] Santhapparaj AS, Alam SS. Job satisfaction among academic staff in private universities in Malaysia. Journal of Social Sciences. 2005;1(2):72-76.

[11] Salmuni W, Mustaffa W, Kamis H. Prioritizing academic staff performance criteria in higher education institutions to global standards. Proceedings of the 13th Asia Pacific Management Conference, Melbourne, Australia. 2007;1281-1288. 
[12] Badri AM, Abdulla HM. Awards of excellence in institution of higher education: An AHP approach. International Journal of Educational Management. 2004;18(4):224-242.

[13] Wayne L. Winston. Operations research applications and algorithms. Duxbury Press Boston; 2012.

[14] Taylor Howard M, Samuel Karline. An introduction to stochastic modelling (3rd Ed.). Academic Press, N. Y.; 1998.

[15] Archibong IA, Effiom DO. ICT in university education: Usage and challenges among academic staff. African Research Review. 2009;3(2):404-414.

() 2017 Akuffo et al.; This is an Open Access article distributed under the terms of the Creative Commons Attribution License (http://creativecommons.org/licenses/by/4.0), which permits unrestricted use, distribution, and reproduction in any medium, provided the original work is properly cited.

Peer-review history:

The peer review history for this paper can be accessed here (Please copy paste the total link in your

browser address bar)

http://sciencedomain.org/review-history/20017 